
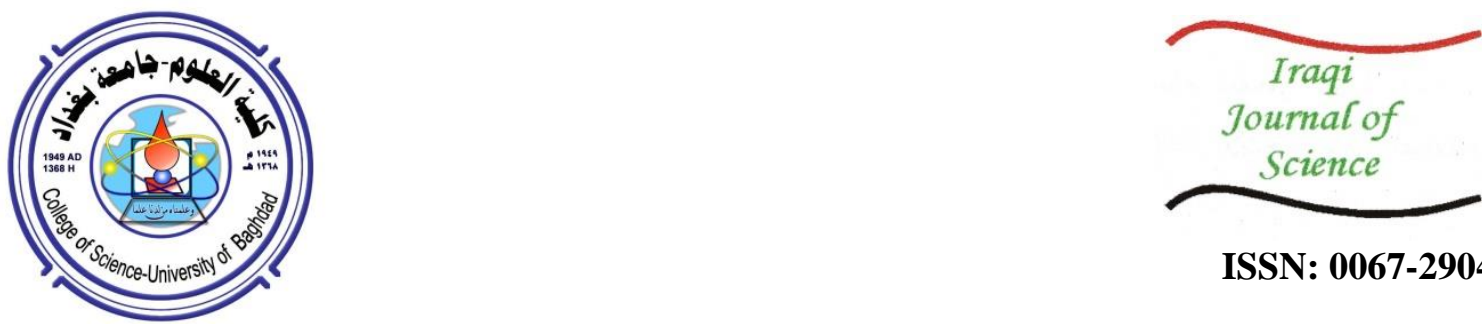

ISSN: 0067-2904

\title{
An Emerging Fault Related Fold (Mahad Anticline) and its Morphotectonic Interpretations in Northern Iraq
}

\author{
Alaa N. Hamdon*1, Rabeea Khalaf Znad ${ }^{2}$ \\ ${ }^{1}$ Remote Sensing Center, University of Mosul/Iraq \\ ${ }^{2}$ Department of Geology, Collage of Science, University of Mosul/ Iraq
}

Received: $13 / 3 / 2020$

Accepted: $12 / 8 / 2020$

\begin{abstract}
In this study, morphotectonic analyses were prepared for an anticline existing to the north of Maqloub Anticline and extends toward north - south approximately, which is unfamiliar in relation to the major extension of the anticlines in the region. The study involves a structural interpretation of the anticline's origin and its relation with the faulting in the foreland zone in this area, specifically in foothill zone, because of the major fracture that is found adjacent and parallel to the axis of this anticline.

The visual interpretation is the major tool used to determine the features of this anticline. Moreover, some facilitating remote sensing technologies, such as digital processing of satellite images and Digital Elevation Model data, were utilized to verify the shape of this geological feature.

The origin of the fold was discussed through its relationship to the associated fault within the general tectonic framework and the surrounding areas. This study addresses the tectonic mechanism of the anticline as a fold-related fault mechanism. As a result, and through the compilation of the above interpretations, a final geological map was prepared for this anticline, along with a 3D model demonstrating its mechanism of folding. Proposed names were given to the anticline and the fault, which are Mahad Anticline and Mahad Fault, according to the name of their nearest town (Mahad Town).
\end{abstract}

Key words: Mahad Anticline, Strike-Slip Fault, Morphotectonic Analyses, Remote Sensing, Iraq

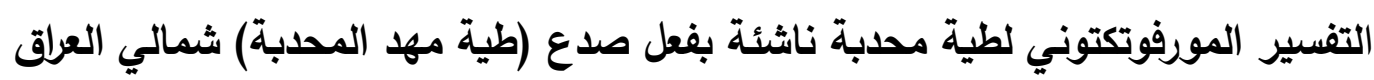

$$
\begin{aligned}
& \text { علاء نبيل حمدون 1" ، ربيع خلف زناد2 } \\
& \text { 'مركز التحسس النائي ، جامعة الموصل، الموصل، العراق }
\end{aligned}
$$

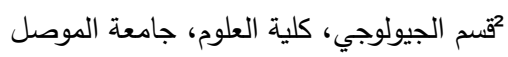

الخلاصه

تم التطرق في هذه الدراسة الى تحليل مورفوتكتوني لتركيب محدب ناشئ يوجد الى الثمال من طية

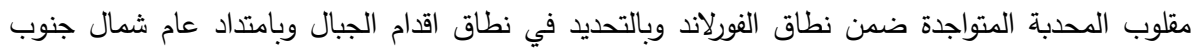

يختلف عن الامتداد السائد للتراكيب المحدبة في المنطقة. اعتمد التقسير البصري الدراسة لتحديد معالم هذا

التركيب المحدب، فضلا عن استخدام بعض التقنيات الاخرى (كأحد طرق المعالجة الرقمية للمرئيات الفضائية

ومعطيات نموذج الارتفاع الرقمي) لتوضيح الثكل التركيبي لهذا المظهر الجيولوجي. تم مناقثة منشأية الطية 


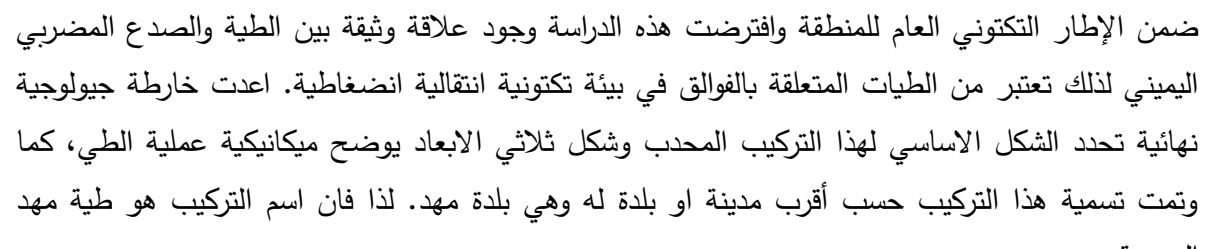

\section{1-Introduction}

The Zagros Foreland Basin in the Arabian Plate is considered as one of the most important areas in which specialized studies have been performed. The study and interpretation of fold structures play an important role in understanding the folding style and tectonic development. In parallel, such studies have remarkable economic value in exploring natural resources, such as oil and gas [1]. Also, the uplift and folding related to the bend of strike-slip faults often create excellent hydrocarbon traps.

Folds in northern Iraq are part of the Western Zagros Fold - Thrust Belt [2]. The predominant trend of fold structures in Iraq is northwest-southeast, following Zagros direction, with some fold structures, such as Sinjar fold, having an east-west trend, following Torus direction,. These are consequences of Zagros collisional orogen between the Arabian plate and the neighboring Iranian and Turkish plates in the late Cenozoic [3].

The presence of an anticline structure with a north-south trend within the folded zone called our attention to focus on this folding structure by performing a structural and morphotectonic interpretation. This study was therefore devoted to the identification of the geological appearance found in the area. The digital elevation model (DEM) data were used to obtain topographical and drainage profiles that may sugest an improvement in the topographical form of the anticline ridges. The studies anticlinal structure is situated in northern Iraq, approximately $40 \mathrm{~km}$ northeast of Mosul City, at the coordinates of $36^{\circ} 35^{\prime}$ $30^{\prime \prime}-36^{\circ} 41^{\prime} 10^{\prime \prime}$ North and $43^{\circ} 20^{\prime} 10^{\prime \prime}-43^{\circ} 24^{\prime} 15^{\prime \prime}$ East (Figure 1).

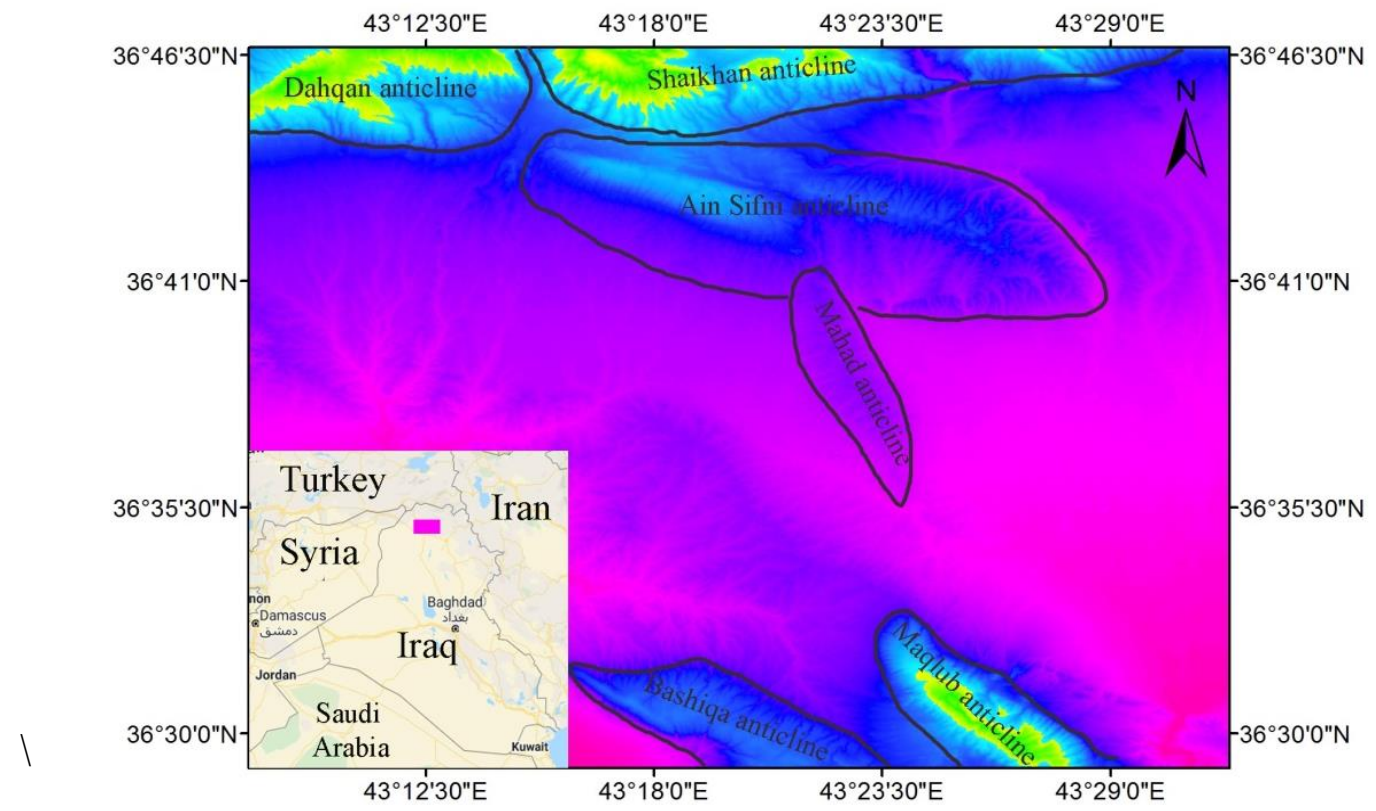

Figure 1- Geographical location of the study area.

\section{2- Geology of the Study Area}

The geology of the study area is characterized by its presence within the area between the foothill zone in the Chamchamal-Batma subzone and the high folded zone, according to the tectonic division of Iraq [4] (Figure 2). 


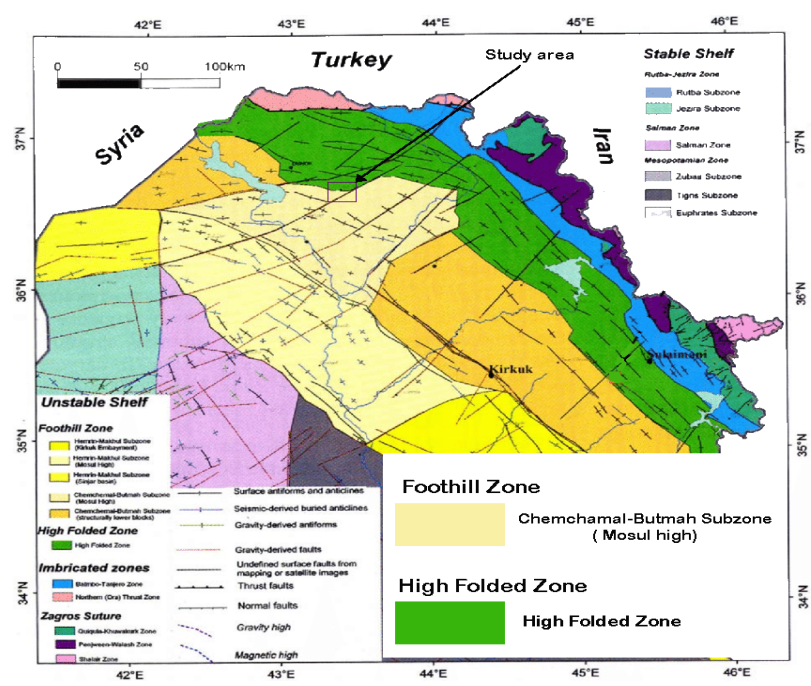

Figure 2- Tectonic map of Northern Iraq, indicating the location of the study area within the tectonic zones [4].

The exposure of the formation in the study area is limited by the fact that this structure is newly formed and of a low amplitude, which is inferred through the recent erosion factors and the formation of modern geomorphological features.

Injana Formation belongs to the middle Miocene [5]. It exposes at the core of this anticlinal structure and forms its main body (Figure-3 A, B). This formation consists mainly of a succession of sandstone and claystone layers. The formation formed structural barriers because of the differential weathering between the hard sandstone and friable claystone beds. Thus, Injana Formation is distinguished in the core of this anticline.
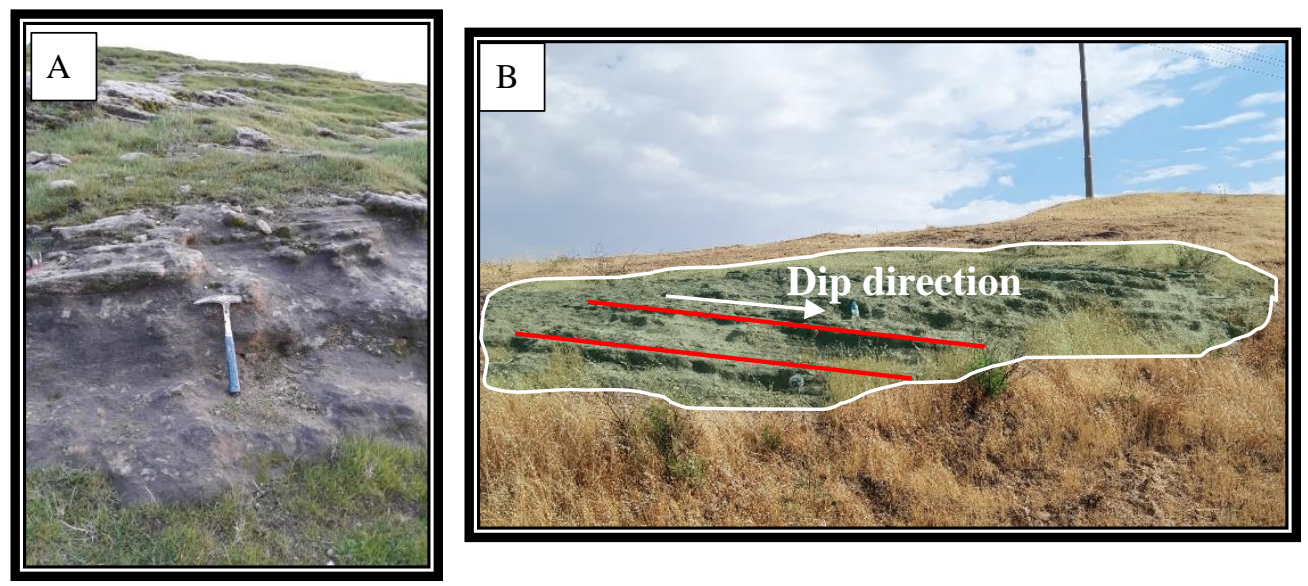

Figure 3-Injana Formation in the study area.

A: at eastern limb $\quad$ B: at western limb

Muqdadiya Formation (Paleocene) is distinguished by the presence of conglomerate, sandy, and clay rocks [6]. This formation is considered as one of the best underground water reservoirs. It forms the predominant outer part and the external structural ridges of the anticlinal structure, especially the southern plunge. Geological maps of the study area were prepared by the Iraqi Geological Survey directorate (Geosurv) [6]. Two accompanied basic geological structures were diagnosed (Figure-4), which are an anticline structure and a fault that extends along with the eastern limb of the anticline. 


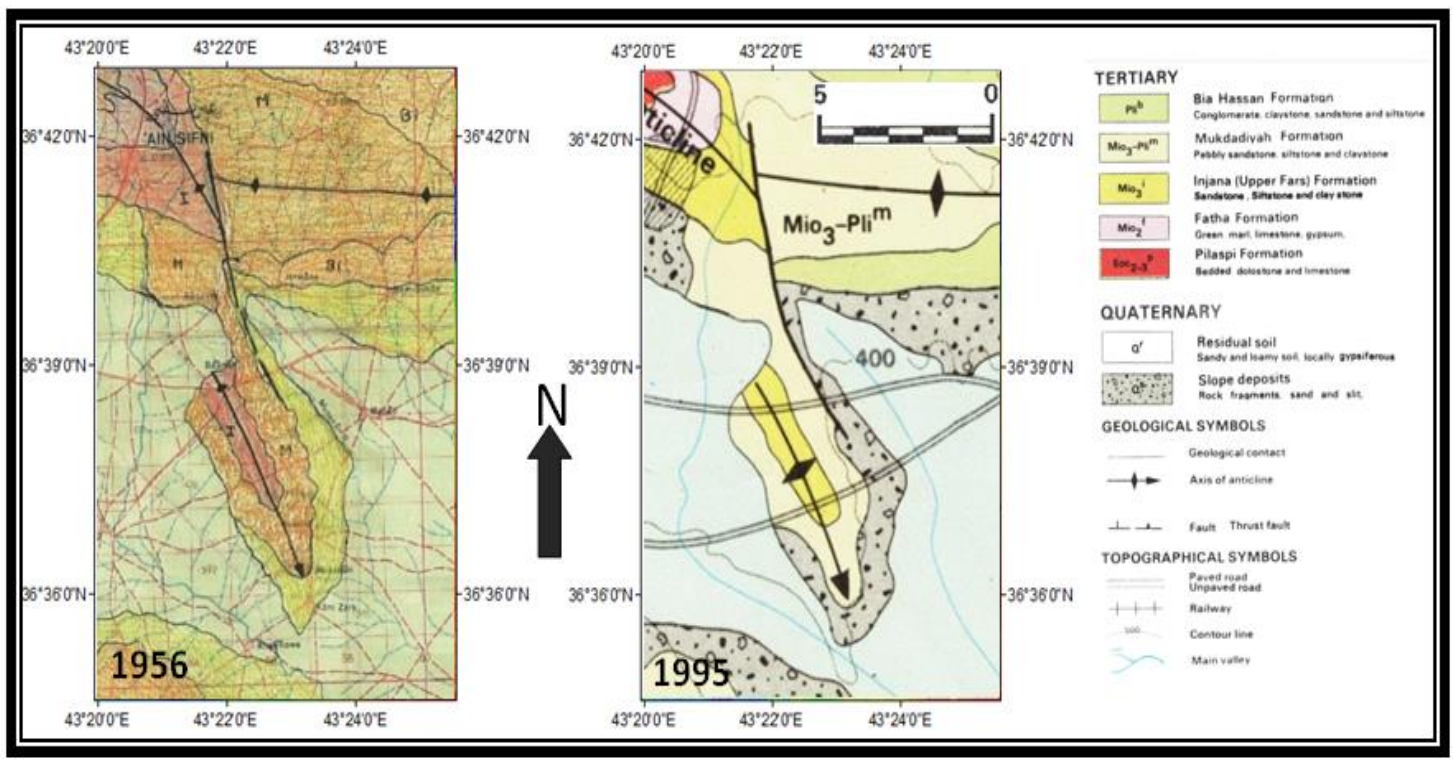

Figure 4- Geological map of the study area according to Geosurv [6].

\section{3- Structural Description of Mahad Anticline}

The outer shape of the anticlinal structure established to be spindle or lozenge shape (Figure-5), as determined by fieldwork and visual observations of the DEM. This study proposed the name of Mahad Anticline for this structure.

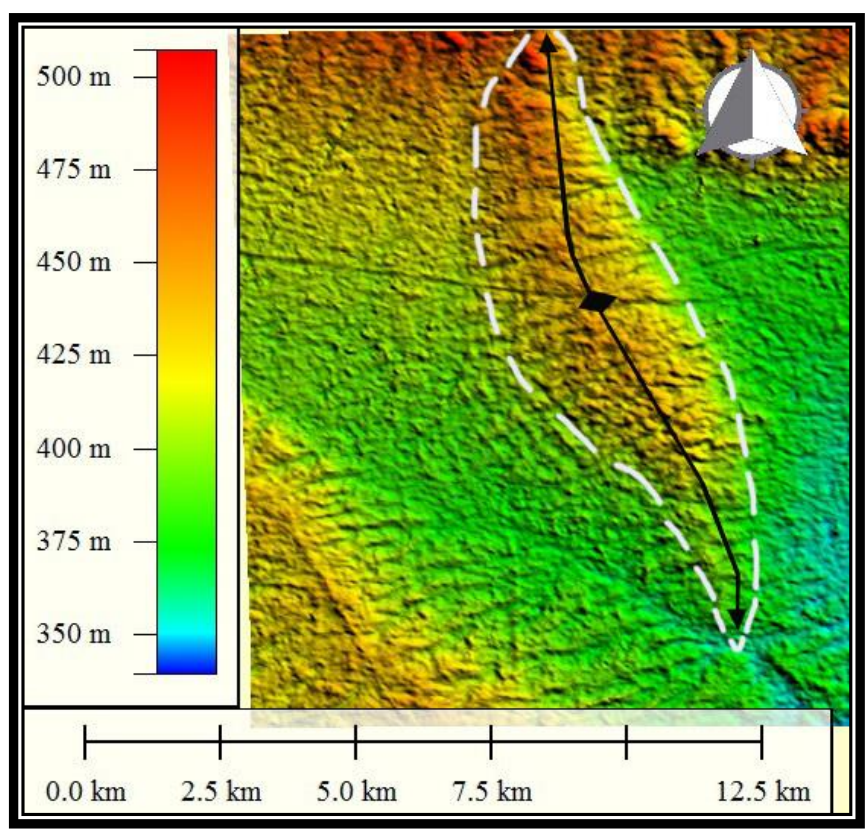

Figure 5- Illustration of the spindle or lozenge shape of Mahad Anticline using digital elevation model.

The fundamental features used to identify fold structures include the longitudinal ridges with two opposite inclinations, flat iron topography, and the V-shape phenomenon (Figures-6). These structures were recognized initially through satellite images and then measured in the field using the Silva compass, where the dipping of the eastern limb is $17^{\circ}$ while the dipping of the western limb is $11^{\circ}$. 


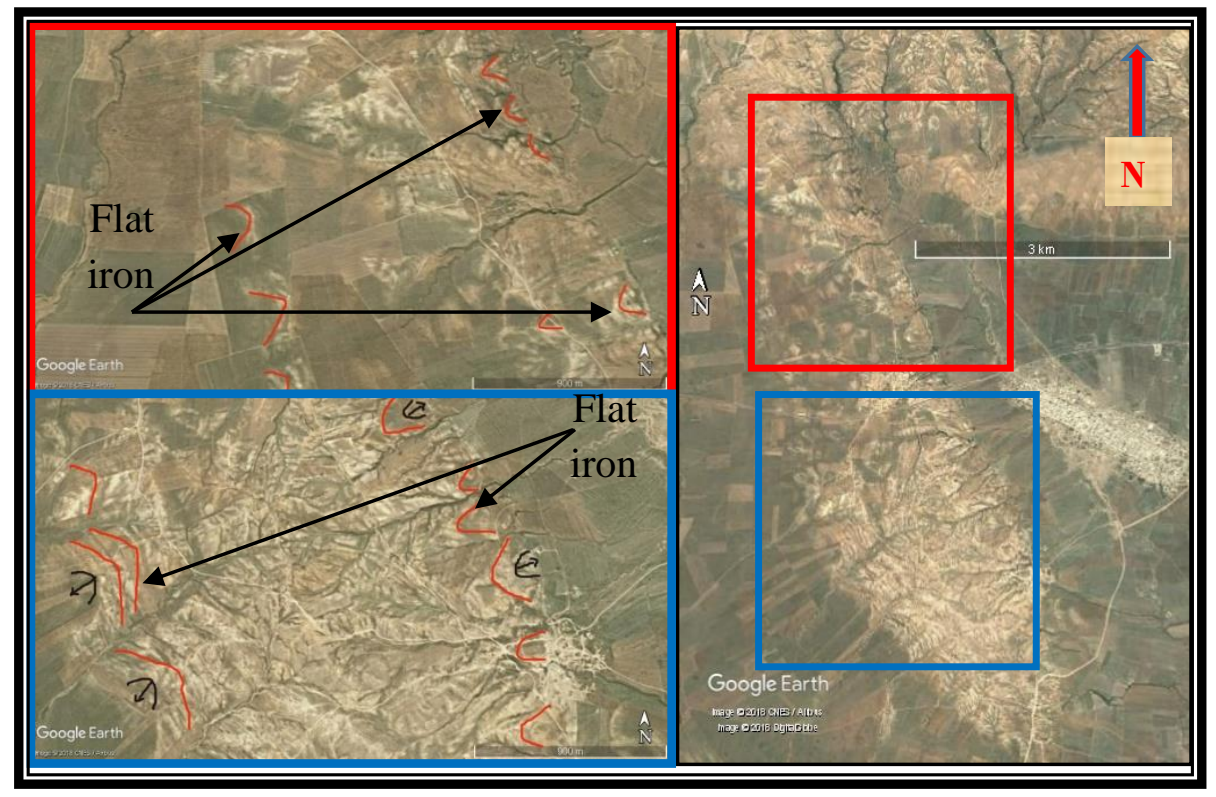

Figure 6- The flat iron topography on both sides of the fold, which indicates the dipping layer slope.

The relationship between the natural drainage patterns and the anticline structure is a an engineering relationship, since most anticline structures are enclosed in a parallel and radial surface drainage pattern on both limbs and plunge noses, respectively [8-9]. Besides, the main drainage divide is perpendicular to the streams on both of its limbs [10-9]. There is a clear drainage divide corresponding to the crestal line, sited close to the more inclined eastern limb. The radial and parallel drainage patterns that are superimposed in the study area (Figure-7) indicate the presence of an anticlinal geological structure, which is the Mahad anticline as defined by this study.

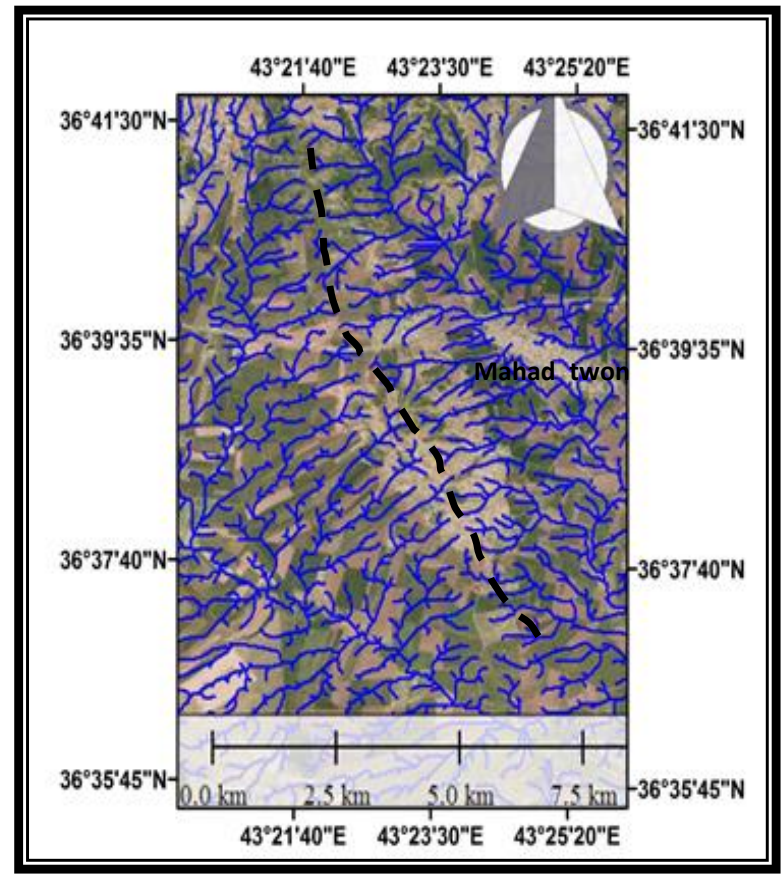

Figure 7- The impact of folding on the drainage pattern shape

The use of one of the digital processing methods of satellite images aided to determine the shape of this anticlinal structure. The method used in this study is the Principle Components Analysis (PCA). 
This technique is used to resume and simplify the data, in that it transforms a large number of inherently variable data into a much smaller set. It extracts as much information as possible from satellite images, then uses them by combining three basic compounds to obtain color images, which make up the bulk amount of information that is segregated clearly (Figure 8).

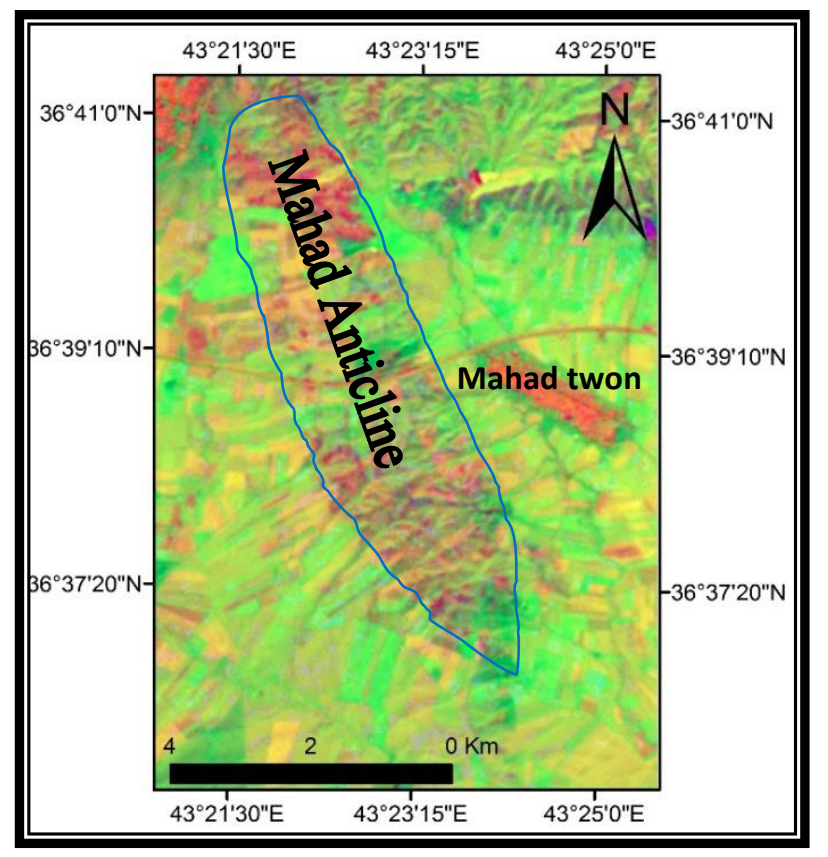

Figure 8- The virtual shape of Mahad Anticline in a false color image prepared with the PCA method.

In this study, six bands of TM Landsat were use to obtain six principal components using ILWIS 1.0 software. Table (1) below shows the Eigenvalue and Eigenvector data of the PCA for the study area. Most data were accumulated within the first and second components, PC1 and PC2, which would imply that most information of land features would exist within these two components.

Table 1 - The eigenvalue and eigenvector data of the PCA in the study area (TM landsat image).

\begin{tabular}{|c|c|c|c|c|c|c|c|c|c|}
\hline \multicolumn{2}{|c|}{$\begin{array}{l}\text { Variance } \\
1192.30 \\
\text { variance } \\
84.27\end{array}$} & $\begin{array}{l}\text { per } \\
205 \\
p \in r \\
4.53\end{array}$ & $\begin{array}{l}\text { band: } \\
-65 \\
\text { centage } \\
1.17\end{array}$ & $\begin{array}{c}6.52 \\
5 \text { per } \\
0.02\end{array}$ & $\begin{array}{c}0.33 \\
\text { and }= \\
0.0\end{array}$ & \multicolumn{2}{|c|}{$\begin{array}{l}0.13 \\
-0.00\end{array}$} & \multicolumn{2}{|c|}{-0.00} \\
\hline \multicolumn{10}{|l|}{$<$} \\
\hline & & & $\mathrm{b} 1$ & 32 & 63 & & b4 & b5 & b6 \\
\hline PC & 1 & & 0.296 & 0.290 & 0.302 & & .304 & 0.568 & 0.568 \\
\hline $\mathrm{PC}$ & 2 & & 0.386 & 0.385 & 0.351 & & .477 & -0.420 & -0.420 \\
\hline $\mathrm{PC}$ & 3 & & -0.578 & -0.337 & 0.057 & & .740 & 0.023 & 0.023 \\
\hline $\mathrm{PC}$ & 4 & & -0.327 & -0.084 & 0.869 & -0 & .358 & -0.029 & -0.029 \\
\hline PC & 5 & & 0.568 & -0.805 & 0.162 & & .064 & -0.003 & -0.003 \\
\hline $\mathrm{PC}$ & 6 & & -0.000 & 0.000 & 0.000 & -0 & . 000 & 0.707 & -0.707 \\
\hline
\end{tabular}

The false color composite was used according to the following composite to conclude the image shown in the figure. This is the best false color composite image to demonstrate rocks, especially in Mukdadiyah and Injana formations, which are not clear in the true color image.

$\mathrm{HSI}=(\mathrm{H}=\mathrm{PC} 1+\mathrm{S}=\mathrm{PC} 3+\mathrm{I}=\mathrm{PC} 4)$

The first, the third, and the fourth components (PCA1, PCA3, and PCA4) were combined to achieve false color images that specify the basic shape of the anticlinal structure, using the ILWIS 3.7 software. The radial type of the drainage pattern is also distinguished on the southern plunge nose of this structure.

\section{4- Mahad Anticline Vergence}

Three cross sections (Figure-9) were drawn perpendicular to the axis of Mahad Anticline with the trend of southwest-northeast, using the Global Mapper software in compatibility with field 
measurements. The first section is near to the southern plunge, the second is in the middle, and the third is near to the northern part of the anticline.
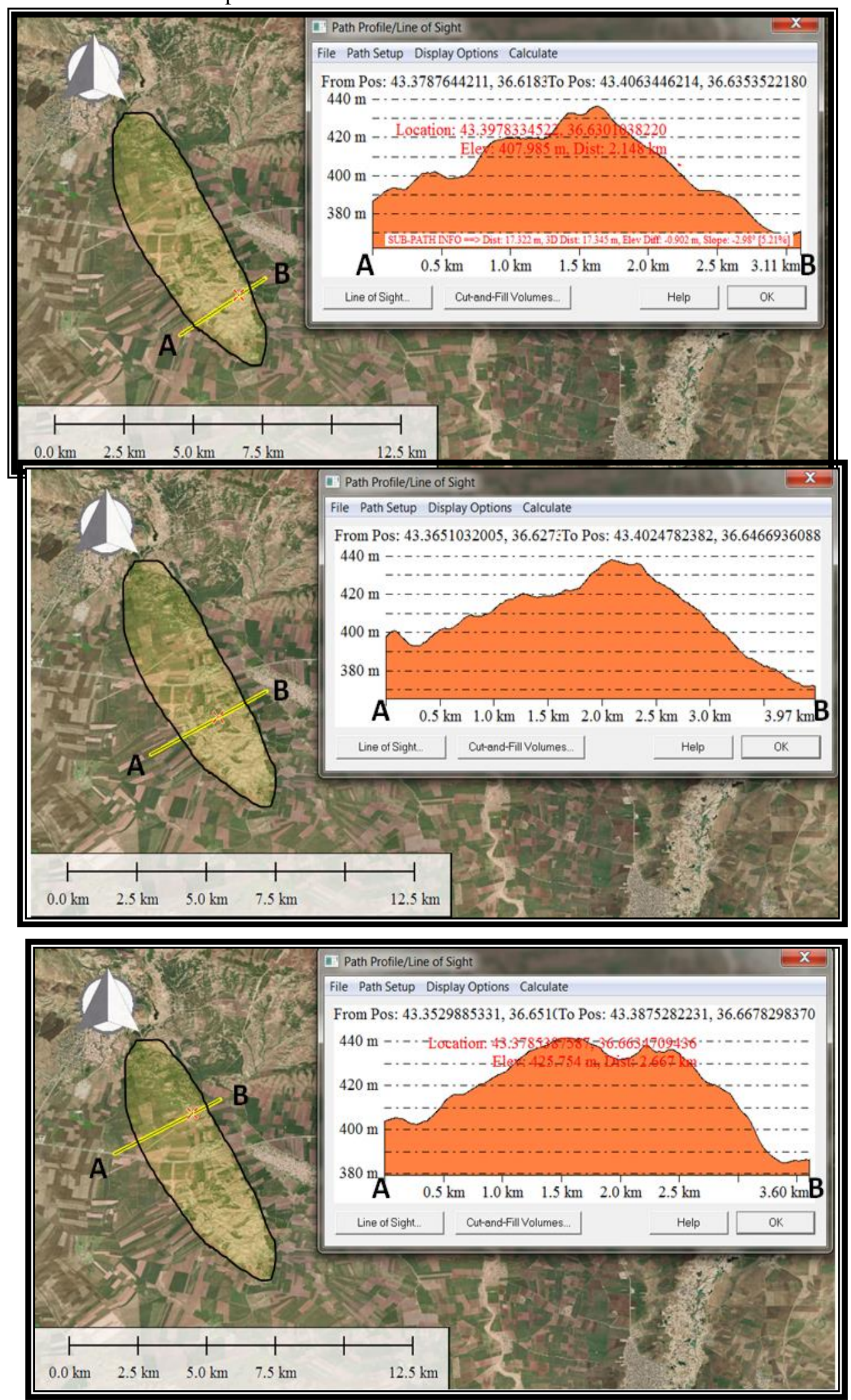

Figure 9- The three cross sections on Mahad Anticline. 
The morphological variation in these sections conceded with a structural fold vergence. The eastern limb has more dipping than that of the western limb and most of Zagros folds in its Iraqi part are associated with fault [11], as the back limb corresponds to the fault dip direction (Figure-10) [12].

Therefore, Mahad Fault may have an eastern vergence.

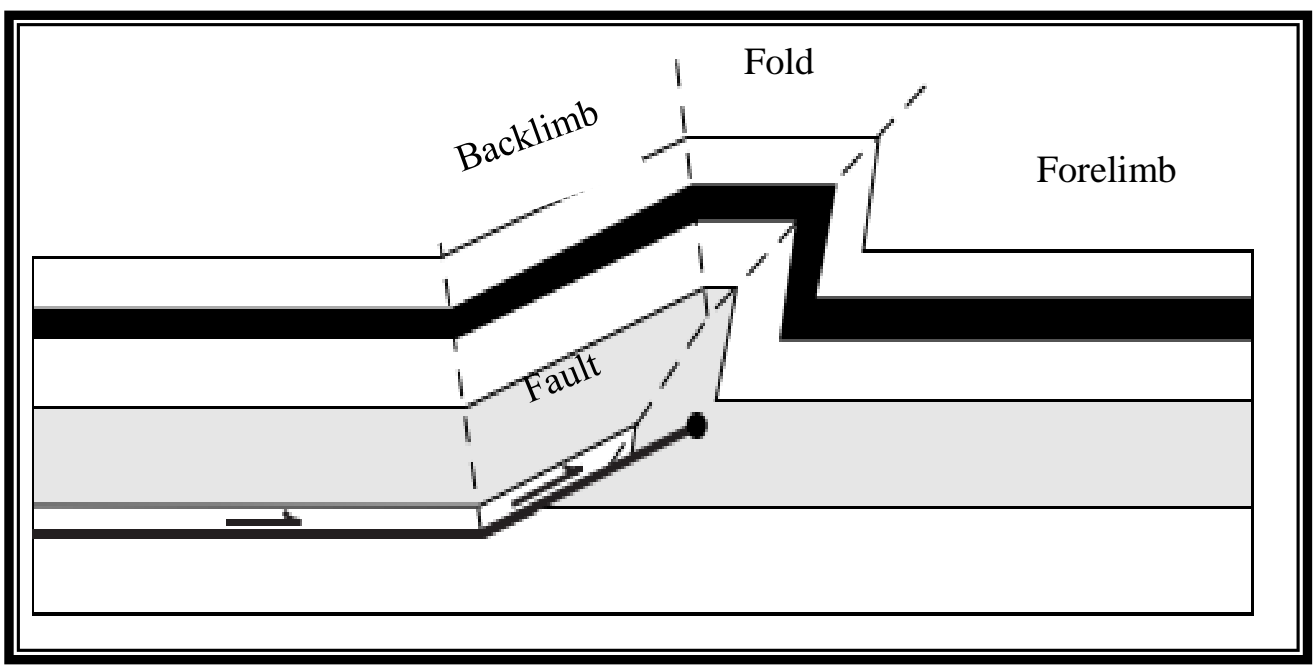

Figure 10 -.In a fold related fault, identical dip direction of backlimb with dip direction of the fault [12].

\section{5 - The relationship of Mahad Anticline with the fault}

Mahad Anticline is an embryonic geological structure that is incompatible with the general trend of the anticlinal geological structures in northern Iraq, which leads to the development of a specific tectonic mechanism for the folding process. The presence of the east verging reverse fault parallel to the eastern flank of this anticlinal structure indicates an increased possibility of a mechanical folding, which is a type of fault- related fold mechanism [13].

The criteria used to deduce the right-lateral strike slip fault are-

First -The fault was recognized and identified by [14].

Second - The Discrete Color renderer was utilized in this study to display the values in the raster dataset of the digital surface model (DSM) for the study area, using the ranged scale of color. The output image (Figure-11) of this technique demonstrates the deformation of topography and land surface, specifically on the east side of the fault which represents an extensional zone in the study area. While the west side of the fault represents a contraction zone, which indicates a dextral strikeslip movement of the fault.

Third -The curve in Pila-Spi Formation outcrops at northwestern plunge of Maqlub Anticline toward to the north is a cause of the deformation by the right-lateral displacement, also the compression of incompetent beds due deformation in the Injana Formation at that part ahead of the plunge consider as another cause by that fault. (Figure-11 A. Figure-12).

Fourth - The deformation of the drainage pattern at the western limb of Mahad Anticline, which exists at the left side of the fault, refers to the right-lateral displacement (Figure-11B).

Fifth -The sharp break of the slope is present as a linear trace of the fault along the eastern limb of the anticline (Figure-11C).

Sixth -This fault was identified and determined by the official authority of geological maps [7] 

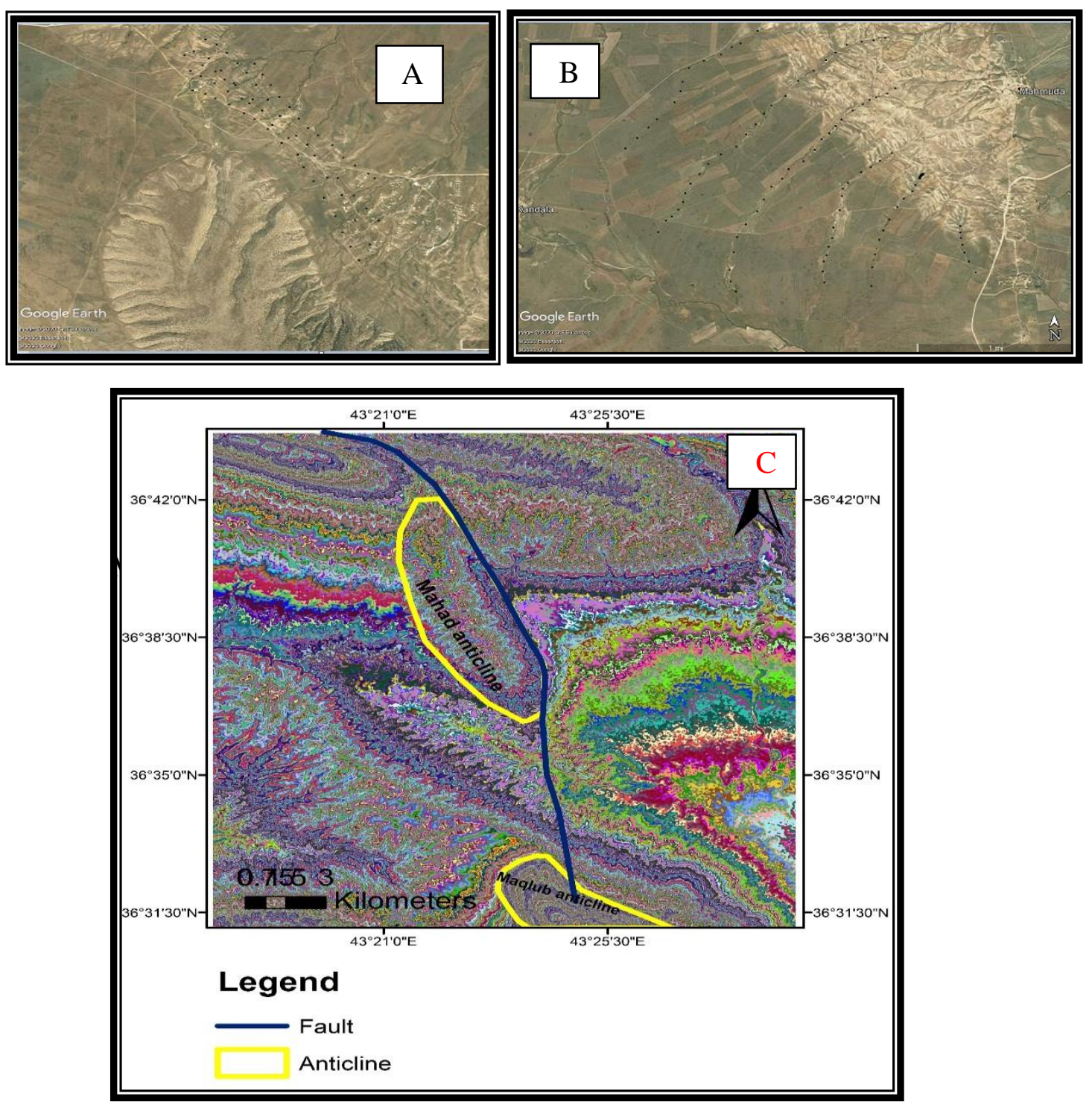

Figure-11 The effects of the dextral strike-slip fault on the study area. A) Curve at northwestern plunge of Maqlub Anticline and deformation of Injana Formation. B) Deformation of the drainage pattern at western limb of Mahad Anticline. C) Linear trace of the fault along the eastern limb of the Anticline

Based on the principle of converging evidence, along with the morphotectonic evidence of this anticlinal structure and its relationship with the surrounding structural elements, the relationship between the Anticline and the Fault formulated as in the following.

First, the spindle appearance of the emerging fold suggests its connection to a sub-surface fault. Also, the eastward vergence of the fold indicates the westward dip direction of the fault.

Second, by connecting Mahad Fold with the stipulated fault described by an earlier study [14] (Figure -12), the intended fault may be a right-lateral displacement (dextral), and this corresponds to the eastward vergence of Mahad Fold.

Maqloub anticline 


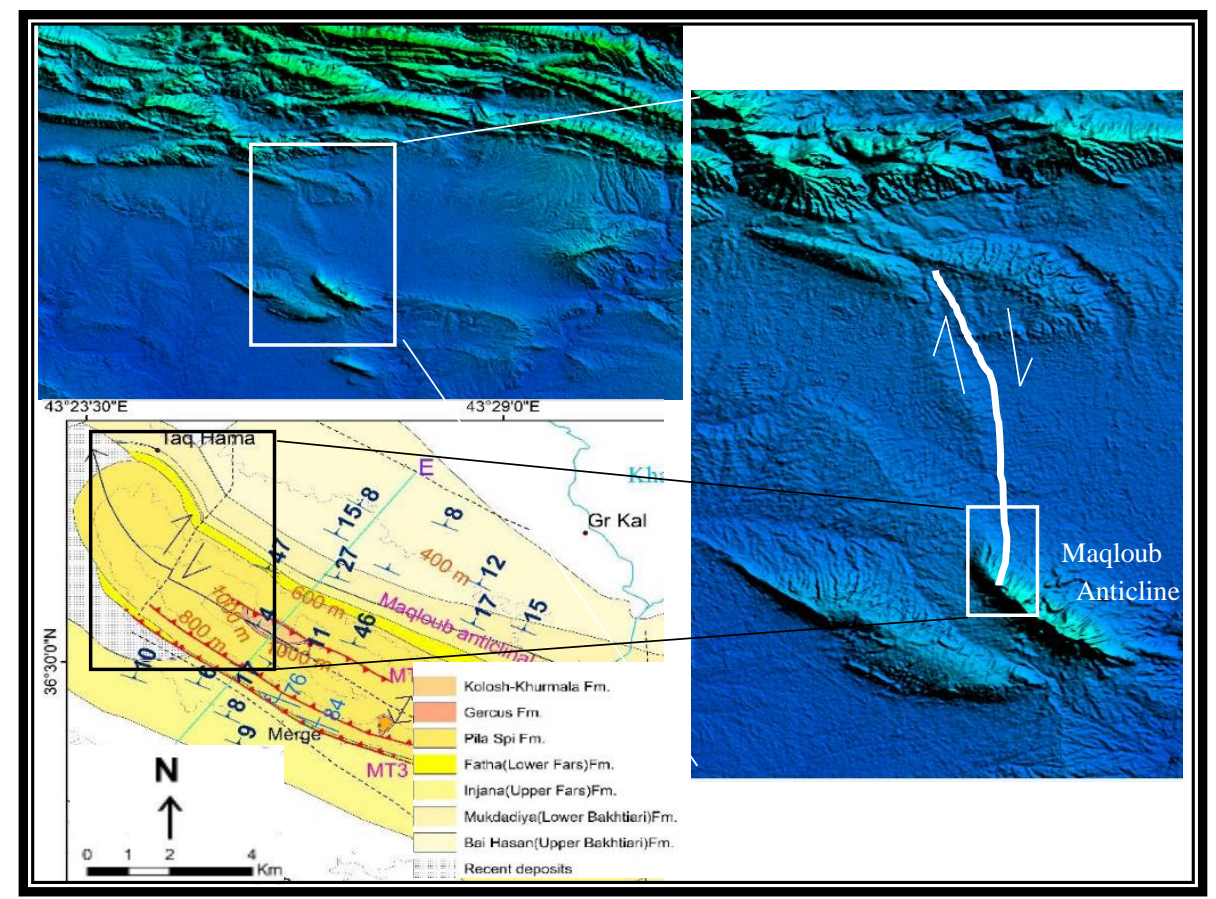

Figure- 12- Major curvilinear dextral strike slip fault that extends towards the Maqloub Anticline affected by it clearly [14]

Third, Mahad Fault is part of a major curvilinear dextral slip fault that

extends to the Maqloub Anticline and is affected on both the plunge and the southeastern limb (Figure -12) [14]. Also, the strike slip fault may have a left-bend in the study area, which is inferred from the fact that the left step on the right- lateral strike slip fault causes the restraining of the bend at the positions where the bend is aligned, so that the blocks on the opposite sides of the fault are pressed together and sitting at localized transpressional deformation (Figure-13) [15-16]. The irregular geometry along the strike-slip fault generated an abundantly restraining bend. This might be due to the pre-existing crustal structures affecting the propagation pattern of the strike-slip fault or the variation of the mechanical properties along the fault during its progressive movement. Such compression systems are, of course, synonymous with the earthquakes of all magnitudes [17].

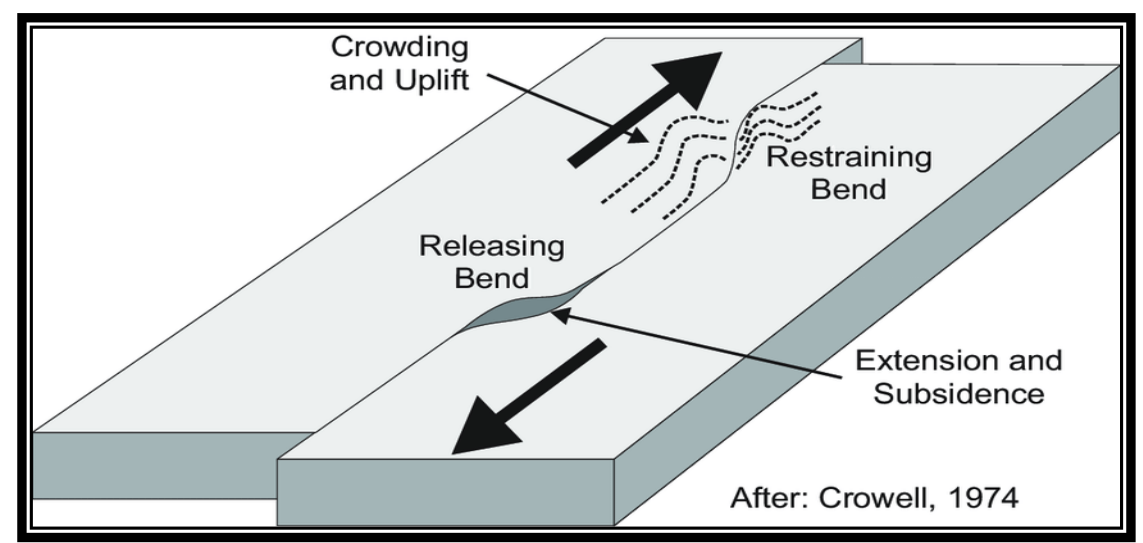

Figure 13- Restraining bend along the a strike -slip fault [15]

Thus, the tectonic of Mahad Anticline may represent a transpressional structure on a gentle restraining bend. Locally, the fault can be a right-hand reverse slip fault with an east vergence .Based on the 
evidence above, a hypothetical model of the folding was prepared (Figure-14) and, to demonstrate the structural and geological settings, a geological map was drawn (Figure-15).

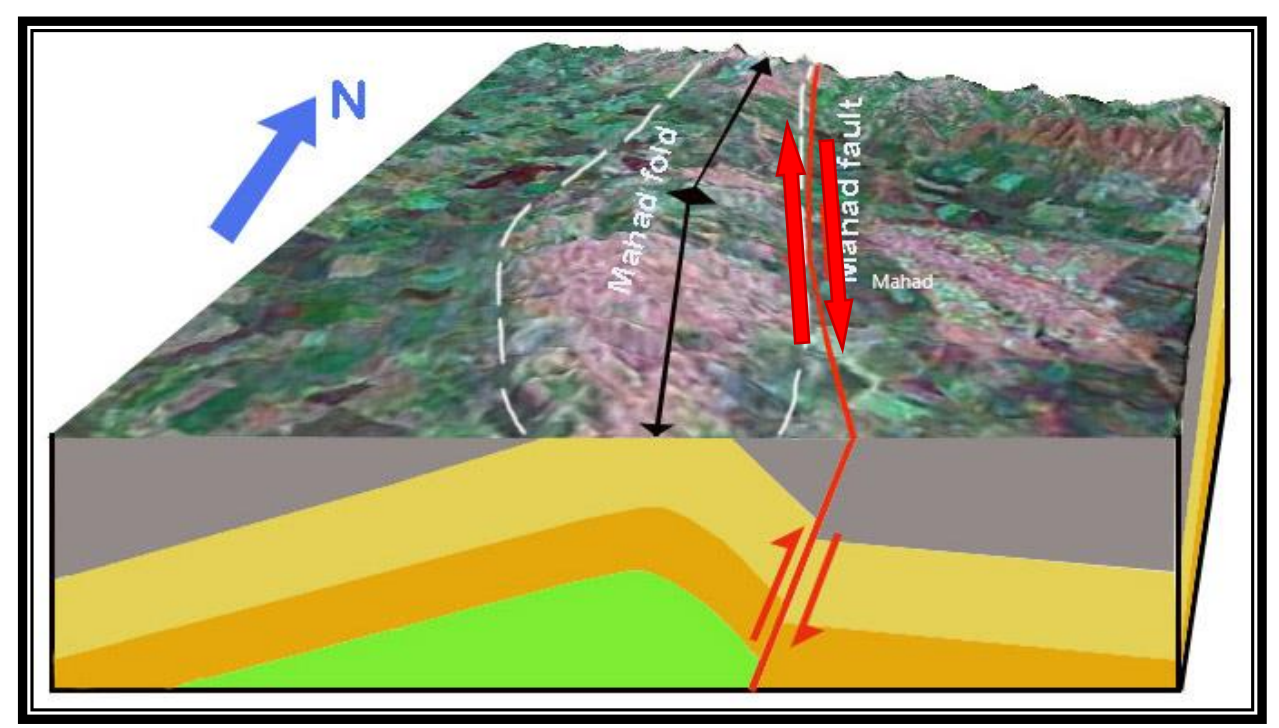

Figure 13- Three-dimensional model of Mahad Anticline mechanism.

The broad existence of the right-lateral strike -slip fault is extending from the Maqloub Anticline, passing the adjacent Mahad Anticline, towards the AinSifni and Shiekhan Anticlines. This may suggest a deep-seated fault that may have penetrated the deep rock formations [18]. As hydrocarbon resources have been explored in the surrounding anticlines, Mahad Anticline can be considered as a candidate hydrocarbon reservoir. Such tectonic situations (i.e., transprssional) have established valuable hydrocarbon reservoirs in other places of the world [19].

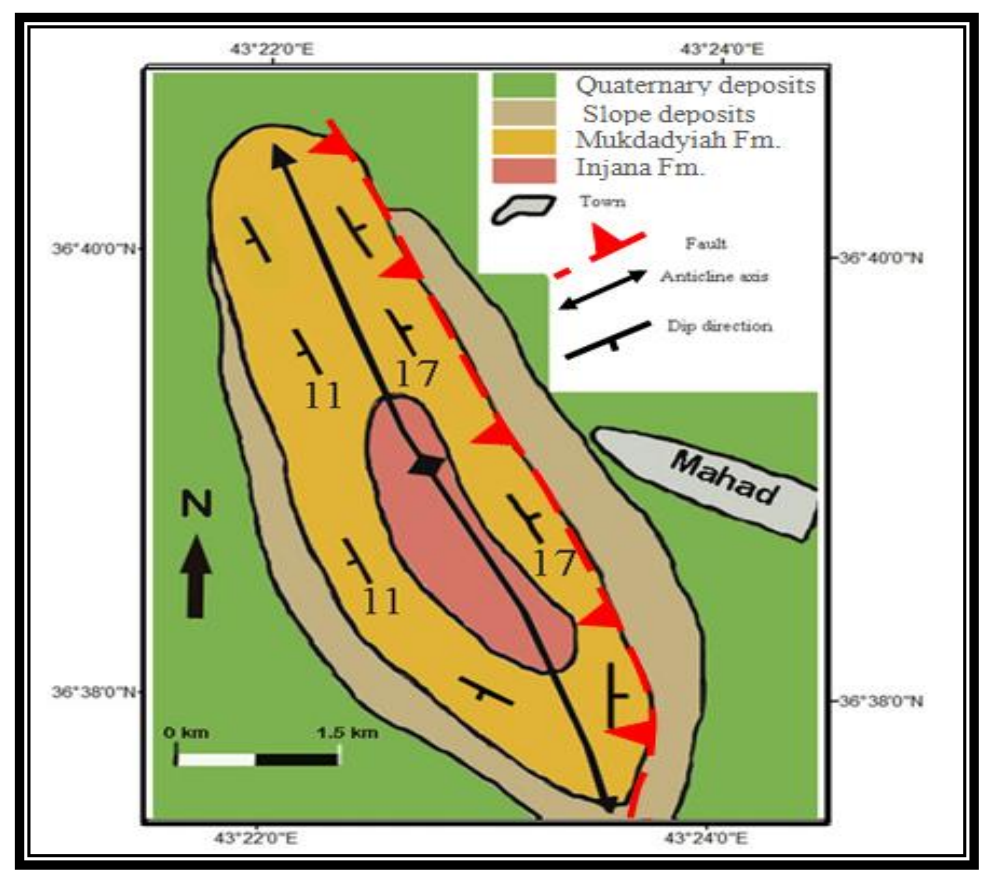

\section{6- Conclusions}

Figure 12- Geological map of Mahad Anticline 
Mahad Anticline that is trending north -south is predictable as a fault related fold, which is created in a transpressional deformation zone in consequence of a left bend step on a major right- lateral strike-slip fault. Locally, the fault segment (Mahad Fault) behaves as a right hand reverse slip fault with vergence to the east, compatible with the eastern vergence of Mahad Anticline. The presence of the study area within this transitional domain between these two main tectonic zones may have caused this particular tectonic environment to form this anticlinal structure.

\section{References}

1. Sharland,P.R.,Archer,R.,Casey,D.M.,Davis,R.B.,Hall,s.h.,Heward,A,P.,Horbury,A.D.,Simmons,M .D. 2001.Arabian plate sequence stratigraphy. GeoArabia. special publication 2, Bahrain, 371P.

2. Fouad, S, F,A. 2014. Western Zagros Fold-Thrust Belt, part П: The High Folded Zone. Iraqi Bulletin of Geology and Mining, Special Issue, No.6, 53 - 7.

3. Emami, H. 2008. Foreland propagation of folding and structure of the mountain front flexure in the pusht-e kuh arc (Zagros,Iran).Ph.D. thesis. University of Barcelona. Geology Faculty. Spain.

4. Jassim, S. Z., and Goff J.C. 2006. Geology of Iraq. Published by Dolin, pargue and Musem, Brno Czech Republic, 2006. 337 p.

5. Buday, T.1980. The regional geology of Iraq (Stratigraphy paleontology). Dar AL-Kutib publishing House, Mosul, Iraq,443 p.

6. Al-Shammary, Th.2009. Sedimentological studies of the Mukdadiya formation south-east of Badra, Iraqi Journal of Science, Vol.50, No.3, 369-375.

7. Geosurv. .1956,1995.Iraq Geological Survey. Geological Map of Iraq (Al-mosul QuarterNJ-3813), 1:25000,1st edition ,state establishment of geological survey and mining, Iraq.

8. Garcia, M. \& Herail, G. 2005. Fault-related folding, drainage network evolution and valley incision during the Neogene in the Andean Precordillera of Northern Chile, Geomorphology journal, Elsevier, Vol. 65, Issues 3-4, 279-300.

9. Jackson, J. A., Richard, \&John Y. 1994. The structural evolution of active fault and fold systems in central Otago, New Zealand: evidence revealed by drainage patterns. Journal of Structural Geology, Vol. 18, Nos 2/3, 217 - 234.

10. Delcaillau, B., Carozza, J.M., Laville, E.2006. Recent fold growth and drainage development: The Janauri and Chandigarh anticlines in the Siwalik foothills, northwest India. Geomorphology, Elsevier, Vol. 76, pp.241-256.

11. Numan, N. M. S., and Al-Azzawi, N. K. B. 1993. Structural and geotectonic interpretation of vergence directions of the anticlines in the Foreland Folds of Iraq, Abhath Al-Yarmouk (pure science and engineering), Yarmok University, Jordan, 2, 2, 57-73.

12. Van der Pluijm, B.A. and Marshak, S., 2004. Earth structure: An introduction to structural geology and tectonics. WCB/McGraw Hill, USA, 495p.

13. Brandes, C., Tanner, D. 2014. Fault-related folding: A review of kinematic models and their application, Earth sciences reviews, Elsevier, Vol. 138, 352-370.

14. Balaki Hassan Ghazi kakAmeen. 2019. Structural Evolution of the Bradost, Pirs, Beara and Maqloub-Baradarash Anticlines in the Zagros Fold Thrust Belt, Kurdstan Region, NE Iraq. Unpub. $\mathrm{PhD}$. theses. Department of Geology, Collage of Science, Saladin University- Kurdistan Region . $240 \mathrm{P}$.

15. Crowell, J. C. 1974. Origin of late Cenozoic basins in southern California. In: Dickinson, W. R. (ed.) Tectonics and sedimentation. SEPM Special Publications, 22,190-204.

16. Fossen Hakon .2010. Stuctural Geology. Cambridge University Press, 436P.

17. Mann, P. Demets, C \& Wiggins-Grandison, M. D.2007. Toward A Better Understanding Of The Late Neogene Strike-Slip Restraining Bend In Jamaica: Geodetic, Geological and Seismic Constraints. From: Cunningham, W. D. \& Mann, P. (Eds) Tectonics of Strike-Slip Restraining and Releasing Bends. Geological Society, London, Special Publications, 290, 239-253.

18. Keller, F.A.; Pinter, N. 2002. Active Tectonices (Earthquakes, up lift, and laudscape). Prentice Hall, NJ. USA. 362P.

19. Legg, M. R., Goldfinger, C., Kamerling, M.J,.Chaytor, J.D., \& Eeinstein,D.E.2007. Morphology, structure and evolution of California Continental Borderland restraining bends. Tectonics of Strike- 
Slip Restraining and Releasing Bends. Geological Society, London, Special Publications, 290, 143-168. 